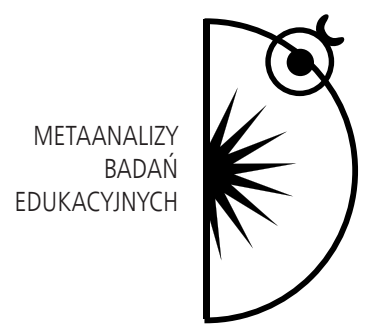

Bogusław Śliwerski

\title{
Diagnoza kompromitujących błędów metodologicznych w koncepcjach (wnioskach) badań pedagogicznych
}

DOI: http://dx.doi.org/10.12775/PBE.2013.002

Przedmiotem moich analiz będą dwie sfery działalności naukowo-badawczej polskich pedagogów, w których najsilniej jest widoczna ich akademicka porażka. Mam tu na uwadze najważniejszą w życiu i rozwoju akademickim potrzebę podwyższania własnych kwalifikacji i naukowego statusu, a więc związaną $\mathrm{z}$ przewodami naukowymi na stopnie i tytuł profesora oraz częściowo $\mathrm{z}$ tym związaną, chociaż realizowaną w zupełnie innych strukturach akademickiego funkcjonowania i weryfikacji kompetencji, jaką jest aplikowanie o środki finansowe z budżetu państwa w Narodowym Centrum Nauki na realizację projektu badawczego. Teza moich krytycznych analiz, które mogłyby służyć nie tylko diagnozie i rozpoznaniu zakresu patologii czy słabości, ale zarazem możliwości ich przeciwdziałaniu czy naprawie, brzmi: im niższe są kompetencje i osiągnięcia naukowo-badawcze pedagogów w toku uzyskiwania przez nich stopni naukowych, tym mniejsze mają szanse na uzyskanie finansowego wsparcia $\mathrm{w}$ realizacji projektu badawczego. Ten bowiem nie może być poprawny, jeśli nie są spełnione $\mathrm{w}$ jego przesłankach podstawowe wymogi poprawności metodologicznej. 


\section{Stan i przyczyny możliwych porażek polskich pedagogów w ubieganiu się 0 awans naukowy}

Spójrzmy na kluczowe dane dotyczące przewodów naukowych na stopień doktora habilitowanego i na tytuł naukowy profesora, w których Sekcja Nauk Humanistycznych i Społecznych Centralnej Komisji Do Spraw Stopni i Tytułów wyznaczała recenzentów w dwóch wyróżnionych przeze mnie okresach. Tym samym dopełniała aktu możliwego uruchomienia przewodów naukowych z dyscypliny pedagogika. Zatwierdzeni przez CK do każdego z przewodów dwaj recenzenci wraz z dwoma wskazywanymi przez jednostki otwierające przewody naukowe mieli trzy miesiące na przygotowanie oceny dorobku naukowego i stwierdzenie o jego nie tylko formalno-prawnej wystarczalności i poprawności, ale i pozytywnym wkładzie w rozwój nauk pedagogicznych. W kraju nikt nie analizował dotychczas stanu rzeczy w tym zakresie ani jego progresu, status quo czy regresu. Postanowiłem zatem na podstawie analizy dokumentacji CK z tytułu własnego członkostwa w tym organie odpowiedzieć sobie na pytanie, czy w ciągu dwóch - dających się formalnie wyróżnić - kadencji CK można rozpoznać główne tendencje procesów awansowych polskich pedagogów. Dane przedstawia tabela 1 .

Tabela 1. Wyznaczanie recenzentów w przewodach naukowych

\begin{tabular}{|c|c|c|c|c|}
\hline $\begin{array}{l}\text { Wyznaczanie recenzentów } \\
\text { w przewodach naukowych }\end{array}$ & razem & pozytywnie & $\begin{array}{l}\text { postępowanie } \\
\text { w toku }\end{array}$ & negatywnie \\
\hline & \multicolumn{4}{|c|}{$\begin{array}{l}\text { I okres: styczeń 2008-grudzień } 2010 \\
\text { (30 miesięcy roboczych) }\end{array}$} \\
\hline \multirow[t]{2}{*}{ Habilitacje } & 71 & 39 & 22 & 10 \\
\hline & \multicolumn{4}{|c|}{$\begin{array}{l}\text { II okres: luty 2011-czerwiec } 2012 \\
\text { (15 miesięcy roboczych) }\end{array}$} \\
\hline \multirow[t]{2}{*}{ Habilitacje } & 58 & 29 & 24 & 5 \\
\hline & \multicolumn{4}{|c|}{$\begin{array}{l}\text { I okres: styczeń 2008-grudzień } 2010 \\
\text { (30 miesięcy roboczych) }\end{array}$} \\
\hline \multirow[t]{2}{*}{ Profesura } & 15 & 3 & 10 & 2 \\
\hline & \multicolumn{4}{|c|}{$\begin{array}{l}\text { II okres: luty 2011-czerwiec } 2012 \\
\text { (15 miesięcy roboczych) }\end{array}$} \\
\hline Profesura & 15 & 5 & 6 & 4 \\
\hline
\end{tabular}


Z przedstawionych danych wynika wyraźny wzrost liczby osób ubiegających się o habilitację i tytuł profesora na podstawie osiągnięć naukowych w dyscyplinie pedagogika. Biorąc pod uwagę drugi okres diagnozy, liczący zaledwie 15 miesięcy, w stosunku do pierwszego, 30-miesięcznego, widać znaczący, bo o prawie 40-procentowy wzrost liczby otwartych przewodów habilitacyjnych, jak i 37-procentowy wzrost ich pozytywnego zakończenia nadaniem stopnia doktora habilitowanego. Podobnie dobra sytuacja dotyczy wniosków profesorskich. O ile w pierwszym okresie było ich 15 , o tyle w drugim, a przecież dwukrotnie krótszym, powstało także 15 przewodów, a więc miał miejsce dwukrotny wzrost, w tym także wyższy wskaźnik pozytywnie przeprowadzonych procedur awansowych na tytuł naukowy. Niestety, odnotowałem dwukrotnie wyższy wskaźnik negatywnych uchwał rad wydziałów w tych postępowaniach.

Można zatem stwierdzić, że formalnie sytuacja jest tylko częściowo zadowalająca. Mnie jednak zainteresował powód, dla którego mieliśmy w Centralnej Komisji do czynienia z odwołaniami naukowców na skutek:

a) niedopuszczenia ich do otwarcia przewodu habilitacyjnego czy w postępowania na tytuł naukowy profesora,

b) nieprzyjęcia kolokwium habilitacyjnego lub nieuznania dorobku na tytuł naukowy profesora (najczęściej w wyniku co najmniej jednej negatywnej recenzji),

c) podjęcia przez jednostkę uchwały o nienadaniu stopnia doktora habilitowanego po wykładzie habilitacyjnym, a pomimo wcześniejszego przyjęcia kolokwium.

Dla zdecydowanej większości kandydatów tego typu sytuacje są nieuzasadnioną porażką. Tymczasem recenzenci Centralnej Komisji, po zapoznaniu się $\mathrm{z}$ dokumentacją przewodu, podkreślali następujące przyczyny nienadania stopnia czy tytułu naukowego:

1. negatywna ocena rozprawy habilitacyjnej w sytuacji, gdy miała miejsce pozytywna ocena wydawnicza habilitacji lub tzw. książki profesorskiej,

2. brak wystarczającego dorobku podoktorskiego lub pohabilitacyjnego (zbyt mała liczba publikacji naukowych),

3. różnice ocen między recenzentami w przewodzie ze względu na przyjęty przez ocenianego paradygmat badań.

Recenzenci CK wskazywali najczęściej na takie argumenty negatywnej oceny dorobku naukowego habilitantów czy kandydatów do tytułu, jak: produkowanie informacji o informacji; brak w rozprawie metodologii badań; brak kwestii teoriopoznawczych; brak wkładu autora pracy w naukę; naiwna, zwulgaryzowana wizja humanistyki; nieznajomość podstawowej literatury przed- 
miotu badań; brak twórczej inwencji; zasłanianie się autorytetami; formułowanie tez bez ich uzasadnienia czy asymetria dorobku naukowego w stosunku do czasu pracy.

\section{Turystyka habilitacyjna}

Nie można nie dostrzec faktu, że wysoki poziom dbałości rad wydziałów o to, by kandydaci spełniali jak najwyższe standardy naukowe, sprzyjał rozwinięciu się w Polsce tzw. turystyki habilitacyjnej na Słowacji, gdzie obowiązują nie tylko inne i niższe w stosunku do krajowych wymagania habilitacyjne czy profesorskie, ale i nie są one poddawane tak ścisłym rygorom merytorycznej weryfikacji, jak ma to miejsce w Polsce. Już w czerwcu 2008 r. miała miejsce wśród członków Komitetu Nauk Pedagogicznych PAN ożywiona dyskusja w związku z nasilającym się zjawiskiem uzyskiwania przez coraz liczniejszą grupe nauczycieli akademickich $\mathrm{z}$ naszego kraju stopni naukowych doktora habilitowanego z pedagogiki i pracy socjalnej, głównie na Wydziale Pedagogicznym Uniwersytetu Katolickiego w Rużomberoku na Słowacji, ale także na Uniwersytecie Mateja Beli w Bańskiej Bystrzycy, Uniwersytecie w Nitrze czy w Preszowie. Proces ten nie dotyczył pracowników o wyróżniających się uzdolnieniach czy zainteresowaniach naukowo-badawczych w ich macierzystych uczelniach, gdyż w naszym kraju nie ma przeszkód w przeprowadzeniu przewodu habilitacyjnego czy na tytuł naukowy z pedagogiki.

Zdziwienie władz podstawowych jednostek organizacyjnych niektórych uniwersytetów wywołał fakt, że w większości przypadków powyższe awanse miały charakter ukryty. O uzyskaniu habilitacji dziekani dowiadywali się już post factum, kiedy wypromowani na Słowacji polscy pedagodzy przedkładali dyplom i potwierdzenie jego zgodności z polskimi normami prawa. Zapanowała totalna dezorientacja, której towarzyszyły (w przypadku władz takich uczelni, jak Uniwersytet Szczeciński, UAM w Poznaniu, UŁ, UMK w Toruniu i UW) podejrzenia co do rzetelności postępowania awansowego poza granicami kraju osób legitymizujących się uzyskanym w Rużomberoku dyplomem. Nie było wówczas wiadomo, ilu osób dotyczył ów proces awansu, na jakich zasadach był on przeprowadzany i czy rzeczywiście spełniał obowiązujące normy prawne².

2 Przewody naukowe Polaków na Słowacji mogą być prowadzone dzięki podpisaniu w dn. 18 lipca 2005 r. w Warszawie „Umowy między Rządem Rzeczypospolitej Polskiej a Rządem Republiki Słowackiej o wzajemnym uznawaniu okresów studiów oraz równoważności dokumentów w kształceniu i nadaniu stopni i tytułów uzyskanych w Rzeczypospolitej Polskiej i Republice Słowackiej". 
W tym właśnie okresie pojawiły się w polskiej (K. Klinger, K. Wigura 2008) i słowackiej (Na Słowacji 2008) prasie niezwykle krytyczne artykuły, wskazujące na to, że właśnie w powyższym uniwersytecie miały miejsce nadużycia ze strony Polaków. Pierwsze sygnały na ten temat były jednak już w 2001 r., ale zostały zignorowane zarówno przez resort szkolnictwa wyższego, jak i środowisko akademickie (J. Sadecki 2001). Ministerstwo Szkolnictwa Republiki Słowackiej 5 września 2008 r. zajęło oficjalne stanowisko w związku z medialną dyskusją w Polsce na temat promocji habilitacyjnych Polaków z pedagogiki w KU w Rużomberoku, stwierdzając m.in., że opisywane fakty muszą zostać wyjaśnione. Kontrolę miała przeprowadzić Słowacka Komisja Akredytacyjna, która w tym kraju łączy badanie jakości kształcenia z wymogami przestrzegania przez uniwersytety standardów naukowych ${ }^{3}$. Uzyskałem pisemną deklarację profesorów - członków KNP PAN - o chęci włączania się w roli recenzentów w przewody naukowe polskich naukowców, jakie będą prowadzone w powyższej uczelni.

Niestety, jak wynika z przedłożonego KNP PAN 16 marca 2011 r. w Warszawie „Raportu o stanie realizacji umowy o współpracy z władzami KU w Rużomberoku", nie zostały spełnione przez stronę słowacką postulaty, by sprawowanie nadzoru merytorycznego nad polskimi habilitacjami przebiegało według ustalonych wspólnie procedur z udziałem członków KNP PAN. Uwzględniono ten warunek tylko w dwóch przypadkach, kierując do mnie prośbę o wyznaczenie dwóch recenzentów z pedagogiki społecznej. Jak się okazało, była ona słuszna, gdyż profesorowie z KNP PAN zaopiniowali oba wnioski negatywnie i dopiero po uwzględnieniu przez habilitantki poprawek i uzupełnień obie kandydatki mogły niemal w dwa lata później przystąpić do postępowania w przewodach habilitacyjnych. Spełniły bowiem wszystkie konieczne warunki. Swoją pomoc w wyjaśnianiu rzetelności przewodów Polaków w Rużomberoku zaoferował także prof. dr hab. L. Witkowski z UKW w Bydgoszczy, który kilkakrotnie prowadził rozmowy z władzami Wydziału Pedagogicznego KU w Rużombero$\mathrm{ku}$, a nawet pozyskał kserokopie niektórych materiałów. Niestety, potwierdzają

${ }^{3}$ W 2008 r. podtrzymano w wyniku rozmów Umowę między Rządem Rzeczypospolitej Polskiej a Rządem Republiki Słowackiej o wzajemnym uznawaniu okresów studiów oraz równoważności dokumentów o wykształceniu i nadawaniu stopni i tytułów uzyskanych w Rzeczpospolitej Polskiej i Republice Słowackiej (18 lipca 2008 r.) jako stanowiącą podstawę prawną do automatycznego uznawania wymienionych w jej treści dokumentów (w tym także dokumentów o nadaniu tytułu docenta) za równoważne z odpowiednimi dyplomami polskimi. Nie ma zapisów umożliwiających odniesienie dyscypliny, w zakresie której nadano słowacki tytuł docenta do dyscyplin, a w zakresie których w Polsce nadawany jest stopień naukowy doktora habilitowanego. 
one tylko przypuszczenia o bardzo niskim poziomie naukowym kandydatów $\mathrm{z}$ naszego kraju.

Komitet Nauk Pedagogicznych PAN zwracał uwagę na trzy aspekty powyższego procesu, które wywołują nie tylko niepokój, ale stawiają całe środowisko akademickie pedagogów przed pytaniem o dalekosiężne następstwa w sferze naukowej i moralno-obyczajowej. Nie bez znaczenia był tu aspekt formalno-prawny postępowań, które w części przypadków mają charakter wyłudzania stopni naukowych z naruszaniem norm prawa słowackiego i polskiego. Komitet Nauk Pedagogicznych PAN nie miał możliwości reagowania na te zjawiska we wszystkich ich negatywnych aspektach, toteż zwrócił się do minister nauki i szkolnictwa wyższego z prośbą o podjęcie interwencji. Stanowisko Komitetu dotyczyło trzech kwestii.

\section{Aspekt formalno-prawny}

1. Wśród Polaków ubiegających się o habilitację z pedagogiki w KU w Rużomberoku byli doktorzy, którzy albo nie zostali dopuszczeniu do otwarcia przewodu habilitacyjnego w jednej z uprawnionych uczelni w kraju, albo ich przewody habilitacyjne zostały podważone przez Centralną Komisję do Spraw Stopni i Tytułu, a zatem nie uzyskali awansu, albo osoby w stosunku, do których trwało postępowanie sądowe w związku z ich nieuczciwością akademicką (plagiaty, łapownictwo). O habilitację z pedagogiki lub pracy socjalnej ubiegali się psycholodzy, lekarze, a nawet teolodzy czy politolodzy, którzy mimo publikacji z własnych dyscyplin naukowych i często niedopuszczenia do otwarcia przewodu habilitacyjnego w Polsce, podjęli działania na Słowacji dotyczące jednak zupełnie innych niż ich własne dyscyplin wiedzy (pedagogika lub praca socjalna). Ich powrót do kraju z słowackim dyplomem habilitacyjnym z pedagogiki czy pracy socjalnej stał się czynnikiem demoralizującym dla części środowiska, niestety, podatnego na „łatwą”, ,szybką” drogę możliwego awansu.

2. Skoro władze Wydziału Pedagogicznego KU w Rużomberoku zgodziły się na konsultowanie $\mathrm{z}$ wiceprzewodniczącym KNP PAN wszystkich wniosków polskich naukowców ubiegających się o habilitację w tej Uczelni, a potem od tego odstąpiły, przeprowadzając poza jego wiedzą i bez udziału w roli recenzentów profesorów z KNP PAN większość przewodów polskich naukowców, to rodzi się podejrzenie o ich wiarygodność. Profesor B. Śliwerski odstąpił zatem na znak protestu od tej 
współpracy w czerwcu 2010 r., informując o tym KNP PAN. W raporcie są odnotowane wszystkie te przewody habilitacyjne, o których informacje zostały pozyskane głównie $\mathrm{z}$ danych na stronach internetowych $\mathrm{KU}$ w Rużomberoku.

3. Zastanawiające jest w powyższych postępowaniach awansowych uruchomienie przez Słowaków we współpracy z polskimi nauczycielami akademickimi „zamkniętego kręgu recenzentów”, który polegał na tym, że wypromowani wcześniej w Uniwersytecie Katolickim w Rużomberoku Polacy stawali się jedynymi recenzentami swoich koleżanek i kolegów z kraju. Najczęściej jako recenzentów pozyskiwano samodzielnych pracowników naukowych z Polski, którzy sami habilitowali się w Rosji lub na Ukrainie albo którzy nie reprezentowali dyscyplin naukowych związanych z przeprowadzanym przewodem habilitacyjnym czy profesorskim naszych nauczycieli.

Niedopuszczalne byłoby w Polsce wyznaczenie recenzenta jedynie ze stopniem doktora habilitowanego w przewodzie na tytuł naukowy profesora, a tak było w jednym z przypadków. Być może zatem podjęcie próby współpracy z KNP PAN miało być tylko „przykrywką” dla działań nagannych, bo naruszających zasady stronniczości, obiektywizmu i rzetelności ocen. Mimo zatrudnienia mnie w tej uczelni, nie zostałem włączony ani do składu rady wydziału, ani do prac komisji, które przygotowywały wnioski habilitacyjne i dopuszczały kandydatów do dalszego postępowania, ani też nie zostałem zapraszony na posiedzenia rady wydziału, w toku których prowadzono postępowania w przewodach naukowych. Być może dlatego, że wielokrotnie protestowałem przeciwko zgłaszanym wnioskom kolejnych kandydatów, których dorobek naukowy w kraju był mi znany jako niespełniający stosownych kryteriów.

4. Istotnym wskaźnikiem podejrzanego tempa i poziomu uzyskania habilitacji na Słowacji jest fakt, że większość Polaków nie ujawniło w bazie OPI jakichkolwiek danych ani na temat ich rozpraw doktorskich, ani też habilitacyjnych w KU Rużomberoku. Mimo że niektórzy habilitowali się z pedagogiki czy pracy socjalnej, podają w bazie OPI, że są socjologami lub wykonują zawód psychologa czy lekarza. Interesujący jest przypadek naukowca z KUL, który w Rużomberoku obronił pracę doktorską w kwietniu 2006 r., a habilitował się w tej samej uczelni w dwa miesiące później, o czym informuje w bazie OPI. Prawdopodobnie część osób przedkładała tam jako habilitację swoja rozprawę doktorską pod zmienionym nieco tytułem. Jest także zaskakujący fakt, że ktoś, kto w kraju 
uzyskał stopień naukowy doktora na podstawie rozprawy na określony temat, w trzy lata później uzyskał w Rużomberoku habilitację, która miała zbliżony temat, a nie została opublikowana.

\section{Aspekt moralny}

Wszyscy wiemy, że „coś jest nie tak” z uzyskiwanymi przez niektórych Polaków habilitacjami czy tytułami profesora na Słowacji, ale nie możemy tego ocenić, gdyż nie dysponujemy wglądem w dokumentację. Wbrew zapisom prawa na Słowacji dysertacje habilitacyjne powinny być opublikowane po przeprowadzonym postępowaniu. Dziwnym trafem polskie dysertacje są niedostępne czytelnikom, którzy mogliby na tej podstawie wyrobić sobie jakikolwiek osąd. Skoro krąży opinia o tym, że jak komuś nie powiedzie się habilitacja czy nie uzyska tytułu naukowego, może udać się na Słowację, staje się to niszczące dla pracy kadr naukowych w kraju, które są uczciwie zaangażowanej w naukę. Jak mamy pracować z młodymi naukowcami, z doktorantami, skoro mają oni świadomość, że w tej kwestii można coś „załatwić inaczej”?

\section{Aspekt naukowy}

Jest niezwykle ważny, bowiem do uczelni publicznych, ale w większości niepublicznych w Polsce trafiają także ci habilitowani po słowackiej stronie nauczyciele akademiccy, którzy nie mają właściwych kompetencji. Te osoby, które przeprowadziły swój awans na Słowacji w sposób rzetelny, ujawniają wszelkie dane na ten temat i angażują się w dalszy rozwój naukowy własny oraz swojego środowiska akademickiego. Nie można zatem tych zjawisk generalizować. Pozostali jednak korzystają z przywilejów, jakie z tego tytułu wynikają, a więc możliwości wielokrotnego zatrudniania się w niepublicznych szkołach wyższych do minimum kadrowego (dydaktycznego). Te jednostki, które kształcą na studiach II stopnia, powinny prowadzić badania naukowe, ale ich kadry nie uczestniczą w życiu naukowym pedagogów i w rozwoju dyscypliny naukowej. Co gorsza, niektórzy doktorzy habilitowani recenzują w kraju, ale także na Słowacji przewody doktorskie i habilitacyjne, przyczyniając się tym samym do reprodukcji tego, co w naukach, dydaktyce oraz prowadzeniu badań jest najgorsze i destrukcyjne. Warto zwrócić uwagę, że tematami wykładów habilitacyjnych i ich rozpraw były w większości przypadków problemy banalne, nic niewnoszące do nauki, znajdujące się na poziomie prac licencjackich czy magisterskich. 
Na podstawie umowy zawartej prawnej między rządami Republiki Słowacji i Rzeczpospolitej Polskiej z 2008 r. ma miejsce równoważność słowackiego tytułu docenta w dyscyplinach naukowych, które w Polsce nie są uznane jako naukowe, a rzecz dotyczy zarówno „pracy socjalnej” jak i tzw. dydaktyk zawodowych. Utrzymywanie w mocy tej Umowy przez MNiSW narusza interes polskiego środowiska naukowego. Wprowadza się bowiem do środowisk akademickich osoby ze statusem, który w Polsce nie jest uznawany za naukowy. Niniejsza Umowa ma w praktyce jednostronny charakter, bowiem nie spotykamy się w dyscyplinie pedagogika z sytuacją, by którykolwiek ze słowackich naukowców zamierzał habilitować się w Polsce czy też ubiegać o tytuł naukowy profesora. Żadna z polskich uczelni nie odnotowała osiągnięć w tym zakresie, natomiast w drugim kierunku mamy do czynienia $\mathrm{z}$ lawinowo narastającym procesem wzrostu liczbowego doktorów habilitowanych ze słowacką docenturą, których dorobku naukowego nikt nie zna, a jeśli, to został on odrzucony przez jednostki akademickie przeprowadzające przewody habilitacyjne czy profesorskie.

Mająca miejsce od 2004 r. tzw. turystyka habilitacyjna na Słowację, praktykowana przez część polskich nauczycieli akademickich, wykładowców czy adiunktów uczelni publicznych i niepublicznych, których dorobek naukowy w żadnej mierze nie pozwala na uzyskanie awansu naukowego w kraju, prowadzi do obniżenia poziomu nauki w kraju. Wybierają oni bowiem procedurę łatwego awansu z dyscyplin, które na Słowacji są traktowane jako naukowe, podczas gdy w Polsce - także w wydanym przez ministerstwo rozporządzeniu o obszarach, dziedzinach i dyscyplinach naukowych - nie znajdują akceptacji, gdyż nie wiążą się z wykorzystywaniem metodologii badań w naukach humanistycznych i społecznych. Nie ma z polskiej strony żadnej oceny jakości i poprawności przeprowadzanych na Słowacji postępowań, co w świetle tak zawartej umowy wymagałoby jednak przynajmniej dokonania oceny zasadności jej utrzymywania we wzajemnych stosunkach.

Przekazany ministerstwu przez Komitet Nauk Pedagogicznych PAN w 2011 r. i w 2013 r. raport w omawianej sprawie zawierał rzeczowe argumenty o wykorzystywaniu przez część środowiska powyższej umowy do omijania standardów naukowych w kraju. Jeśli na tym ma polegać pogłębianie współpracy w dziedzinie nauki między obu krajami, to w ciągu najbliższych lat nastąpi głęboki kryzys i upadek polskiej nauki, gdyż będą nią zarządzać i oceniać innych ci, którzy nie spełniają standardów metodologicznych. Komitet Nauk Pedagogicznych PAN zwrócił się zatem do MNiSW z prośbą o zweryfikowanie zasadności utrzymywania Umowy z Rządem Republiki Słowackiej lub dostosowanie jej zapisów w zakresie, który liczyłby się z polskimi wymogami na- 
ukowymi, a nie - co ma miejsce dotychczas - radykalnie obniżał ich poziom i upełnomocniał kadry o niskich kwalifikacjach (szerzej: B. Śliwerski 2011a, 2011b, 2011c, 2011d).

\section{Rywalizacja polsko-polska w kraju i na Słowacji}

Toczy się zatem od kilku lat swoistego rodzaju „skryta rywalizacji” między tymi nauczycielami akademickimi, którzy nie potrafią lub z różnych powodów nie chcą i nie zamierzają weryfikować poziomu i zakresu własnych osiągnięć naukowych w Polsce, orientując swoją aktywność na spełnienie wymogów uczelni słowackich, a tą większością, która nie tylko chce, potrafi, ale i dąży do aktywnego włączania się w proces rozwoju nauk pedagogicznych w kraju, dokumentując to swoimi osiągnięciami naukowymi i przeprowadzając postępowanie awansowe w jednostkach akademickich polskich uczelni. Przeprowadzona przeze mnie analiza postępowań awansowych Polaków na Słowacji przedstawia się następująco:

Tabela 2. Zestawienie pozytywnie zamkniętych przewodów habilitacyjnych i profesorskich polskich pedagogów w krajowych uczelniach i na uniwersytetach Słowacji

\begin{tabular}{|c|c|c|c|}
\hline $\begin{array}{c}\text { Czerwiec 2008- } \\
\text {-czerwiec 2012 } \\
\text { rodzaj przewodu }\end{array}$ & POLSKA & $\begin{array}{r}\text { POLACY } \\
\text { NA SŁOWACJ }\end{array}$ & proporcje \\
\hline HABILITACJE & 68 & 33 & $2: 1$ \\
\hline PROFESURY & 9 & 13 & $1: 1,5$ \\
\hline
\end{tabular}

Źródło: oprac. własne.

Kiedy przyjrzymy się problematyce rozpraw i wykładów habilitacyjnych Polaków na Słowacji (w zdecydowanej większości nieopublikowanych w kraju, a nawet na Słowacji), to widać wyraźnie, że nie przekraczają one w wielu przypadkach problematyki typowej dla prac magisterskich czy nawet licencjackich, stając się podstawą do uzyskania stopni i tytułów naukowych. Oto najbardziej charakterystyczne przykłady takich tematów habilitacji Polaków na Słowacji: Wspótczesny model autorytetu nauczyciela; Profilaktyka i terapia uzależnień wśród młodzieży; Formy spędzania czasu wolnego przez dzieci katolickiego wyznania; Kara fizyczna a agresywność dziecka. Zastanawiający jest fakt habilitowania się na Słowacji doktorów w większości wypromowanych w Instytucie 
Badań Edukacyjnych w Warszawie, który to Instytut w wyniku przeprowadzonej kontroli przez Centralną Komisję w 2010 r. miał zawieszone uprawnienia do nadawania stopnia doktora nauk humanistycznych $\mathrm{w}$ dyscyplinie pedagogika na okres trzech lat. Przypadek to czy pewna prawidłowość?

\section{Stan i przyczyny możliwych porażek polskich pedagogów w ubieganiu się 0 granty naukowe w konkursach Narodowego Centrum Nauki}

Wraz z powołaniem Narodowego Centrum Nauki i zmianą Ustawy o zasadach finansowania nauki polscy naukowcy mają coraz mniejsze środki na badania własne w ramach budżetów uczelni, toteż muszą zabiegać o nie w powyższej instytucji (Ustawa). Ta zaś ogłasza co kilka miesięcy konkursy, których zasady i sposób finansowania są niezwykle transparentne oraz obwarowane wysokimi standardami kontroli formalno-prawnej i etycznej. W rozpatrywaniu wniosków badawczych liczy się nie tylko dorobek naukowy wnioskodawcy, ale i nowatorski charakter problemu badawczego, konceptualizacja badań i najwyższe standardy metodologiczne oraz organizacyjne gwarantujące ich realizację. Polscy pedagodzy są przypisani do panelu HS6, w ramach którego zarówno osoby rozpoczynające karierę naukową, młodzi doktorzy, jak i już doświadczeni badacze mogą ubiegać się o środki na badania podstawowe.

Analizując wyniki panelu HS 6 „Człowiek i życie społeczne” w NCN w 2011 r. w ramach pierwszego konkursu, do którego przez pedagogów, socjologów i psychologów zostało zgłoszonych łącznie 354 wniosków, odnotowałem, że $40 \mathrm{z}$ nich zostało odrzuconych ze względu na niespełnienie kryterium badań podstawowych, a 12 z tytułu wymogów formalnych (przekroczenie pięciu lat po uzyskaniu stopnia doktora przez wnioskodawcę; zaprojektowanie dłuższego okresu realizacji badań, niż zostało to określone w warunkach konkursu czy przekroczenie kosztów aparatury - powyżej 150 tys. zł). Tym samym co siódmy projekt badawczy został przygotowany niezgodnie z obowiązującymi, a klarownie określonymi kryteriami. W większości odrzucanych wniosków okazało się, że nie dotyczą one oryginalnych prac badawczych eksperymentalnych lub teoretycznych, które miałyby być podejmowane przede wszystkim w celu zdobywania nowej wiedzy o podstawowych zjawiskach i obserwowalnych faktach bez nastawienia na bezpośrednie praktyczne zastosowanie lub użytkowanie. Wyniki badań mogą znaleźć zastosowania praktyczne, ale projekty w ramach tych konkursów muszą być ukierunkowane na badania, spełniające ustawową definicję badań podstawowych. 
Ocena projektów ma dwuetapowy charakter. W pierwszej fazie są one oceniane przez ekspertów z danej dyscypliny naukowej. Jeżeli uzyskają konieczny do przejścia do drugiego etapu recenzji próg punktowy, to wówczas są kierowane do kolejnych najwyższej rangi ekspertów, także zagranicznych. Poziom rywalizacji jest zatem bardzo wysoki, a nie toczy się w obrębie wnioskodawców jednej dyscypliny naukowej, ale trzech: pedagogiki, psychologii i socjologii. Pula środków jest ograniczona, a zatem rywalizacja ma tu charakter gry o sumie zerowej, antagonistyczny. Środki finansowe na badania mogą uzyskać tylko najlepsze projekty w ramach owej puli. Przy ocenie wniosków uwzględnia się poziom naukowy badań lub zadań przewidzianych do realizacji, nowatorski charakter problemu naukowego, którego rozwiązanie jest proponowane, osiągnięcia naukowe zespołu wykonawców, zasadność planowanych kosztów w stosunku do przedmiotu i zakresu badań, wpływ realizacji projektu badawczego na rozwój dyscypliny naukowej, ocenę wykonania przez wnioskodawcę projektów badawczych uprzednio finansowanych ze środków finansowych na naukę.

Jeżeli uwzględnimy to, że w pierwszym konkursie wśród kryteriów oceny projektów ich waga rzutowała na szanse kandydatów, to musimy wziąć pod uwagę ten fakt w wynikach jego rozstrzygnięcia. W 50\% o jakości wniosku decydowały osiągnięcia naukowe wykonawcy projektu, w 30\% poziom naukowy badań i zadań do realizacji, w 10\% kosztorys i w 10\% możliwość wykonania projektu (zaplecze badawcze). Takiego progu nie mogliby zatem przekroczyć ci, którym wydawało się, że nie mając odpowiedniego poziomu osiągnięć, metodologicznych kompetencji, a dysponując jedynie słowackim dyplomem doktora habilitowanego, będą mogli konkurować o środki na badania własne. $Z$ analiz kwalifikacji wnioskodawców lub członków zespołów badawczych jednoznacznie wynikało, że niektórzy z nich nie mieli nic wspólnego z badanym problemem. Nie tylko tożsamość naukowa projektu nie pokrywała się z tożsamością naukowo-badawczą promotora (autora projektu), ale i wskaźnik cytowań jego publikacji (indeks Hirscha) był u pedagogów najczęściej na poziomie 0-2, toteż nie mogli uzyskać maksymalnej liczby punktów. Jak wskazywali recenzenci najsłabszych projektów z pedagogiki, były one: przeciętne lub wątpliwe poznawczo, brakowało w nich informacji odnośnie do wiedzy wnioskodawcy o literaturze światowej z zakresu badanego tematu. Brakowało także dowodów na to, że znane są wnioskodawcy fakty gromadzone przez współczesnych badaczy zjawiska czy procesu, który miałby być przedmiotem badań.

Spójrzmy, jak prezentuje się poziom naukowy wniosków pedagogów w porównaniu z projektami zgłaszanymi w tych samych konkursach przez socjologów i psychologów. Dane z tabeli 3 ilustrują stan tej sytuacji. Wytłuszczeniem 
zaznaczyłem liczbę wniosków, które zostały zakwalifikowane już do finansowania jako bardzo dobre lub wyróżniające się na drugim etapie oceny w stosunku do ogólnej liczby projektów na tym poziomie (ich liczba została umieszczona w nawiasie). W konkursie ogólnym, w którym mogli ubiegać się o środki dojrzali badawczo naukowcy, głównie samodzielni pracownicy naukowi lub doktorzy z dużym dorobkiem, po drugim etapie zakwalifikowano do finansowania z pedagogiki na 16 wniosków, zaledwie dwa, podczas gdy z psychologii na 65 wniosków 40 uzyskało środki, zaś z socjologii na 51 aż 22. Wskaźnik sukcesu progowego wśród wniosków pedagogicznych był zatem bardzo niski. Nieco lepiej wyglądała sytuacja w konkursie dla młodych doktorów, bo tu na 12 wniosków $\mathrm{z}$ pedagogiki zostało zakwalifikowanych do finansowania pięć, zaś w grupie wniosków dla doktorantów na 28 wniosków przeszły wyżej tylko cztery wnioski. Najwyżej zostały ocenione granty psychologów, których wskaźnik sukcesu wynosi ponad 50\%. Znacznie wyżej i więcej wniosków socjologicznych, chociaż mniej w stosunku do psychologicznych zostało zakwalifikowanych do wyższego etapu. Niniejsze zestawienie pokazuje wyraźnie dystans poziomu naukowego wniosków, jaki dzieli pedagogów, psychologów i socjologów.

Tabela 3. Liczba wniosków z pedagogiki, psychologii i socjologii, które zostały dopuszczone do finansowania po II etapie kwalifikacyjnym w konkursach NCN w 2011 r.

\begin{tabular}{|c|c|c|c|}
\hline $\begin{array}{c}\text { Projekty zakwalifikowane } \\
\text { w I etapie do finansowania }\end{array}$ & Pedagogika & Psychologia & Socjologia \\
\hline $\begin{array}{c}\text { Z zakresu badań podstawowych - } \\
\text { ogólne } \\
\mathrm{N}=134\end{array}$ & $2(16)$ & $40(65)$ & $22(51)$ \\
\hline $\begin{array}{c}\text { Dla osób posiadających stopień } \\
\text { naukowy doktora } \\
\mathrm{N}=65\end{array}$ & $5(12)$ & $23(31)$ & $15(22)$ \\
\hline $\begin{array}{c}\text { Dla osób bez stopnia naukowego } \\
\text { doktora } \\
\text { N=146 }\end{array}$ & $4(28)$ & $43(63)$ & $24(55)$ \\
\hline $\begin{array}{c}\text { Międzynarodowe projekty } \\
\text { niewspółfinansowane } \\
\text { N=10 }\end{array}$ & $0(1)$ & $6(7)$ & $63(130)$ \\
\hline Razem & $11(57)$ & $112(163)$ & $2(2)$ \\
\hline
\end{tabular}

Legenda: dopuszczone do II etapu w ramach puli grantów do finansowania; (w nawiasie-odrzucone). 
Studiując treść recenzji wniosków z pedagogiki, które zostały odrzucone, odnotowałem następujące uwagi krytyczne:

1. Autor nie wykazał się znajomością literatury dotyczącej interesującego go problemu z obszaru badań psychologicznych - sam się do tego przyznaje i dopiero, jak pisze, planuje się tym zająć. Nie przeszkadza mu to jednak w twierdzeniu, że takich badań w zasadzie nie ma. Nie ma w projekcie badawczym odniesień do licznych badań; brak spójności pomiędzy tematem, słowami kluczowymi a deklarowanym efektami. Pozycje przytaczane w literaturze, sposób opisywania kwestii w kolejnych częściach projektu, opis programu badań nie wykraczają poza ramy pojęciowe, które dziś dla pedagogiki mają znaczenie głównie historyczne.

2. Wniosek jest niestaranne przygotowany, tak jakby jego autorzy nie czytali poleceń ze zrozumieniem. Projekt badawczy jest słabo osadzony $\mathrm{w}$ teorii, niewystarczająco uzasadniony teoretycznie, często ateoretyczny albo eklektyczny, w założeniach badań występuje sprzeczność paradygmatyczna. Projekt nie jest niczym oryginalnym, nie „wnosi” nic nowego do nauki. Autor zamierza weryfikować znane poglądy na dany temat. Wnioskodawca proponuje banalny temat na poziomie studenckich prac dyplomowych. Projekt jest jałowy poznawczo za sprawą naiwnego założenia. Treść projektu tylko częściowo jest związana z jego tytułem. Tytuł projektu nie rozstrzyga, czy są to badania metateoretyczne czy praktyczne.

3. Brakuje danych pozwalających z większą dozą optymizmu zakładać wykonalność tematu. Skoro nie ma modelu badanego zjawiska ani choćby hipotetycznego modelu ścieżki jego rozwoju - to jak można dobierać narzędzia badawcze? Jaka będzie ich trafność, skoro nie wiadomo, co jest ich koncepcyjną podstawą? A jeśli nieznana jest trafność, to jak można wyciągać $\mathrm{z}$ tych badań jakiekolwiek wnioski?

4. W projekcie brakuje porządnego zaplecza koncepcyjnego, co skutkuje brakiem podstaw do wyboru takich, a nie innych narzędzi badawczych, ale przede wszystkim do sensownych interpretacji uzyskanego materiału empirycznego. Projekt jest niedojrzały pod względem naukowym. Zdrowy rozsądek i wiedza potoczna, nie poddane żadnym rygorom myślenia, nie dostarczą wartościowego pod względem poznawczym materiału. Stare koncepcje, stary sposób myślenia, brak odniesień do współczesności.

5. Język opisu nie jest naukowy, zastąpiła go ideologia i westchnienia autora. Jest zbiorem stereotypów i potocznych sformułowań, niepopartych literaturą przedmiotu. Nie rozróżnia się terminów teoretycznych od terminów obserwacyjnych. Nie operacjonalizuje się pojęć teoretycznych 
(brak wskaźników). Brak umiejętności tłumaczenia języka teorii na język empirii. Według jakich kryteriów będzie prowadzona analiza treści? Nie wystarczy zaznaczyć, że będzie to analiza krytyczna, gdyż trzeba najpierw wskazać, jak ona będzie prowadzona, według jakiej metodologii?

6. Projekt jest nadmiernie uwikłany w konflikty wewnętrzne uniwersytetu X; zlekceważono konieczność uzasadnienia celu, założeń badawczych i metodologii badań; poprzestano na ogólnikach. Cały opis jest bardzo uproszczony i powierzchowny. Opis projektu jest niezwykle pogmatwany.

7. Najczęściej brak problemu badawczego, jego uszczegółowienia, a poszczególne elementy przesłanego projektu: cele naukowe, metodyka, jego efekty, znaczenie i zastosowanie wyników są mało spójne. W przypadku problematyki badań zostały źle postawione pytania (zakłada się stan rzeczy, który nie występuje, ale jest podyktowany względami propagandowymi); błędne wyobrażenie o badanych osobach, przeświadczenie jakoby musiały mieć konkretny pogląd czy wiedzę.

8. Proponuje się badania diagnostyczne, które nie wnoszą nic nowego do dotychczasowej wiedzy teoretycznej, jeśli jest ona już dobrze ugruntowana, np. niepowodzenia szkolne; agresja w szkole, uzależnienia młodzieży itp. Autor nie uzasadnia metod i doboru próby. Próba badawcza jest najczęściej zawężona do własnych studentów lub nauczycieli. Opis planowanej procedury „eksperymentalnej” jest zbyt ogólny, aby można było ocenić jego wartość z punktu widzenia celów badawczych. Metodyka postępowania i badania budzi wątpliwości. Nie wiadomo, jak będą wyglądały eksperymenty. Czym i jak będzie się manipulować? Jak będzie wyglądał pomiar zmiennej zależnej?

9. Autorzy nie rozróżniają problemów naczelnych (ogólnych) i szczegółowych. By móc rozwiązać problem główny, należy najpierw rozstrzygnąć pytania podporządkowane. Autorowi nie udało się postawić problemu wprost ani pośrednio, przez opis metody, więc projekt trzeba uznać za nienaukowy. Co jest jednak podstawowym pytaniem, na jakie autor szuka odpowiedzi? Opis projektu to w zasadzie podręcznikowa prezentacja; prosty opis podstawowych kwestii, brak ujęcia problemowego, brak modelu badanego zjawiska.

10. Wnioskodawca nie wyłania zmiennych, nie definiuje ich, nie operacjonalizuje zmiennych (brak wskaźników lub niekompletna ich lista). Nie jest jasny schemat kontroli badanych zmiennych. Brakuje próby ukazania wskaźników empirycznych adekwatnych do pojęć teoretycznych. 
11. W projekcie nie ma żadnych hipotez, a więc nie wiadomo, co badacz chce ewentualnie rozstrzygnąć. Brak hipotez czy jakichkolwiek pytań badawczych ukazujących nowatorstwo projektu eliminuje go z obszaru poczynań naukowych.

12. Autor nie zna reguł tworzenia narzędzia diagnostycznego, a to właśnie jest celem badań opisanych w projekcie. Autor nie podaje schematu analizy danych. W paradygmacie badań jakościowych brak jest planu badań, metod weryfikacji uzyskanych danych. Autor ignoruje obowiązek poddawania danych rzetelnej analizie. $\mathrm{O}$ metodach analizy danych nie wspomina się wcale. Metody badań jakościowych nie są już dodatkiem, uzupełnieniem do współczesnej metodologii, ale dysponują naukowymi uzasadnieniami procedur, jakie zamierza badacz wykorzystać. Wywiady powinny być rejestrowane w jednorodny sposób, a nie jak projektuje autor: albo spisywane, albo nagrywane, bo ich jakość nie będzie porównywalna. Brakuje informacji na temat sposobu badania kategorii jakościowych.

13. Bibliografia źródeł jest zaskakująco uboga i tendencyjna, ograniczona w dużej mierze do książek o charakterze popularnym, brakuje powołania się na wiarygodne źródła słownikowe i encyklopedyczne, które powinny stanowić punkt wyjścia przy definiowaniu podstawowych pojęć. Bibliografia jest przygotowana niestarannie, nieuporządkowana alfabetyczne.

14. Uderzającą cechą tego projektu są długie ciągi słów pozbawione znaczenia. Projekt może i ciekawy, ale zważywszy na nagromadzenie we wniosku błędów - literowych, językowych, gramatycznych, składniowych, interpunkcyjnych, ortograficznych, logicznych - trudno się skupić nad jego istotą!

15. Zła konstrukcja kosztorysu. Wyróżnione zadania nie są zbieżne z kosztorysem, brakuje też uzasadnień dla planowanych wydatków, np. brak zasad planowanych honorariów, brak uzasadnień dla wyjazdów zagranicznych czy brak uzasadnienia zakupu sprzętu, planowanie całych kosztów - zamiast części na wydawnictwa, planowanie pokrycia kosztów przewodu doktorskiego lub habilitacyjnego, co jest niedopuszczalne; wysokość środków podana nie jest właściwie uzasadniona.

\section{Zakończenie}

Reasumując, przytoczone dane liczbowe o przeważających niepowodzeniach w przewodach naukowych oraz w staraniach o zewnętrzne finansowanie własnych projektów badawczych, w tym treść recenzji ekspertów na temat powodów 
ich odrzucenia, dobitnie świadczy o niskim poziom kompetencji metodologicznych naukowców polskich w dyscyplinie pedagogika. Odnoszę wrażenie, że niedouczeni promują niedouczonych, a rady wydziałów bezkrytycznie otwierają przewody naukowe pod ich kierunkiem. W tej sytuacji polska pedagogika nie ma szans na uczestniczenie w rywalizacji międzynarodowej, skoro nie jest w stanie podjąć jej we własnym kraju. Mamy ewidentnie do czynienia z głęboką zapaścią w zakresie znajomości i rozumienia metodologii badań w naukach humanistycznych i społecznych. Mimo bardzo bogatej już literatury z tego zakresu, wielu konferencji, szkół, warsztatów, sytuacja nie ulega poprawie.

\section{Bibliografia}

Klinger K., Wigura K. (2008), Do świata nauki tylnymi drzwiami. Słowacka fabryka polskich profesorów, „Dziennik” środa 3 września, za: http://www.dziennik.pl/wydarzenia/article231664/Slowacka-fabryka-polskich-rofesorow.html (dostęp: 13.07.2012).

Koniec z dyplomami ze Stowacji. Wywiad z Barbara Kudrycka (2008), „Dziennik” piątek 5 września, za: http://www.dziennik.pl/wydarzenia/article232744/Habilitacje-beda-wedlug-innych-zasad.html (dostęp: 13.07.2012).

Na Stowacji: Pol'sko: Kde l’ahko príst’k titulu? Na Slovensku (2008), „Pravda” 25 listopada, za: http://spravy.pravda.sk/tlac.asp?r=sk_svet\&c=A080903_151443_sk_s...pdf (dostęp: 3.09.2008)

Poliaci chodia na Slovensko za lacnými titulmi, „Pravda” 12 września 2008.

Sadecki J. (2001), Do kariery na skróty. Habilitacje bez polskiego sita - ciagg dalszy, „Rzeczpospolita” 23 maja, za: http://new-arch.rp.pl/artykul/337812_Do_kariery_na_skroty. html (dostęp: 23.05.2001).

Śliwerski B. (2011a), Autodegradacja pedagogiki jako nauki i kierunku kształcenia, w: J. Szempruch, M. Wojciechowska, J. Karczewska (red.), Kultura-edukacja. Ciagłość i tendencje zmian, Wydawnictwo LIBRON; Uniwersytet Humanistyczno-Przyrodniczy Jana Kochanowskiego w Kielcach, Kielce.

Śliwerski B. (2011b), Anomia akademickiej pedagogiki z jej własnym udziałem, w: M. Jaworska-Witkowska, L. Witkowski (red.), Przeszkody dla rozwoju humanistyki w szkotach wyższych (z pedagogika w tle). W perspektywie troski o uniwersytet, kulturę humanistyczna i podręczniki, Wydawnictwo Adam Marszałek, Toruń.

Śliwerski B. (2011c), O przewodach habilitacyjnych i profesorskich z pedagogiki społecznej (pracy socjalnej) oraz z dydaktyk szczegółowych Polaków na Słowacji w latach 2006-2011, „Rocznik Pedagogiczny”, t. 34.

Śliwerski B. (2011d), Klinika akademickiej pedagogiki, Oficyna Wydawnicza „Impuls”, Kraków.

Ustawa o zasadach finansowania nauki, Dz.U. Nr 96 poz. 615. 


\section{The diagnosis of discredited, methodological errors in applications (concepts) of educational research}

\section{Summary}

The subject of my analysis will be two areas of Polish teachers research activities, in which the most visible is academic failure. I have in mind the most important in life and the academic development need for the improvement of academic skills and what is more, increase of their scientific status. Academic status is related to the research, which leads to degrees and the title of professor. It is partly related with the verification of competences, which means to apply for funds from the state budget of the National Science Center on a research project.

The thesis of my critical analysis, that could be used not only to diagnose the pathology and diagnosis of the weaknesses, but also the possibility of preventing or repairing them is presented below: The lower the competences and research achievements of teachers in the course of obtaining their degrees, the less are the chances to obtain financial support for their research projects. It can not be correct, if there are not fulfilled the basic evidences of methodological correctness requirements. 